\title{
Hydrology effects on propagule bank expression and vegetation in six Carolina bays
}

\author{
B. S. Collins ${ }^{1}$ and L. L. Battaglia ${ }^{1,2}$
}

\author{
${ }^{1}$ Savannah River Ecology Laboratory, P. O. Drawer E, Aiken, SC 29802, USA. Fax: +1 8037253309 , \\ E-mail:collins@srel.edu \\ ${ }^{2}$ Present Address: Louisiana State University, Department of Biological Sciences, 508 Life Sciences Building, \\ Baton Rouge, LA 70803, USA
}

\begin{abstract}
Keywords: Depression wetlands, Propagule bank, Recruitment, Wetland organization.
Abstract: Hydrology, which filters propagule bank expression, differs among Carolina bay wetlands. We examined the relationships among hydrology, recruitment from the propagule bank, and bay vegetation over one season in six herbaceous bays that differ in hydroperiod. Sediment cores were taken at distances from each bay center representing $10 \%, 25 \%, 50 \%$, and $75 \%$ full water level and subjected to flooded, midsummer drawdown, or moist soil conditions in an outdoor mesocosm experiment. Vegetation from the cores was compared among hydrology treatments and with bay vegetation. In bay vegetation, species richness and dissimilarity, calculated among replicate plots at each distance, increased from flooded bay centers toward the margins, where water level fluctuated. Among bays, vegetation richness increased from more pond-like bays to the flashiest bay. Within bays, vegetation graded from obligate wetland species to a mixture of obligate and facultative species from center to margin. The flooding treatment promoted convergence on obligate wetland floating-leaved and emergent species, low species richness, and high community similarity of vegetation from the sediment cores. Our research supports the hypothesis that hydrology filters recruitment and species distribution in Carolina bays. The extent of inundated, fluctuating water, and exposed sediment areas can determine seasonal vegetation organization in such wetlands. Vegetation in wetlands with steep basins and stable hydrology is more likely zoned; dominant species show discontinuous distributions along the flooding gradient. In contrast, fluctuating hydrology in shallow basins results in unzoned vegetation, with more continuous species distributions from wetland center toward the margins.
\end{abstract}

Abbreviations: KW - Kruskal-Wallis, SAS - Statistical Analysis System, SREL - Savannah River Ecology Laboratory, SRS Savannah River Site

Nomenclature: Radford et al. 1968

\section{Introduction}

Hydrology is a primary filter on the composition and distribution of wetland vegetation (Mitsch and Gosselink 1993). Depth and duration of flooding can influence germination or emergence and subsequent plant survival (van der Valk 1981, Gerritsen and Greening 1989). Species adapted to inundation establish and persist in areas with extended flooding and deeper water; these floatingleaved and emergent species are distributed over a water depth gradient (van der Valk and Davis 1978, Lessmann et al. 1997, Grace and Wetzel 1998). Fluctuating water levels provide periodic recruitment opportunities for species in the seed bank (Gerritsen and Greening 1989, Keddy and Reznicek 1982, Leck and Simpson 1994), and extended dry conditions allow upland species to encroach (Gerritsen and Greening 1989, van der Valk and Davis 1978). In general, species distributions can be bounded by flood tolerance at the wetter end of the gradient, and in some cases by drought tolerance at the drier end of the gradient (Bauder 1989). Biotic interactions can also limit distributions of species (Bertness and Yeh 1994) and may become more intense where abiotic conditions are less harsh (Hacker and Bertness 1999, Lenssen et al. 1999. Weaker competitors can be displaced along the flooding gradient (Grace 1990, Grace and Wetzel 1998).

Temporal and spatial variation in hydrology is a key feature of Carolina bay wetlands. These elliptical depression wetlands, which extend throughout much of the Atlantic Coastal Plain and are most common in the Carolinas (Sharitz and Gresham 1998, Taylor et al. 1999), span a wide hydrologic gradient. Typical Carolina bays fill over winter, are maximally full in spring, and dry down over summer (Schalles and Shure 1989). The rate and extent of filling and drying are influenced by rainfall and evapotranspiration (Sharitz and Gibbons 1982, Schalles and Shure 1989), the degree of isolation from the water 
table (Lide et al. 1995), basin morphology, and landscape setting (Brinson 1993). These factors contribute to variation in hydroperiod among bays and among years. Bays range from pond-like wetlands, characterized by a stable hydroperiod, to flashy bays that respond quickly to rainfall events and can dry partially or completely at intervals during summer (Kirkman and Sharitz 1994, Poiani and Dixon 1995). The hydroperiod for Rainbow Bay, a pondlike wetland in South Carolina, ranged from 3 - 391 days flooded per seasonal cycle over 16 years (Semlitsch et al. 1996).

Striking differences in dominant vegetation type occur among Carolina bays (Bennett and Nelson 1991, Kelley and Batson 1955, Kirkman et al. 1996, Poiani and Dixon 1995, Schalles et al. 1989, Sharitz and Gibbons 1982, Workman and McLeod 1990). These differences appear to be related primarily to differences in hydroperiod (Keough et al. 1989, De Steven 1994, De Steven and Toner 1997, Sharitz and Gresham 1998), substrate, and disturbance history (Bennett and Nelson 1991, Kirkman et al. 1996, DeSteven and Toner 1997). Some bays on clay-based substrates are forested wetlands, dominated by Taxodium ascendens or hardwoods such as Nyssa sylvatica var. biflora, Acer rubrum, and Liquidambar styraciflua (Bennett and Nelson 1991). Pocosin-like bays, dominated by shrubs such as Lyonia lucida, Cyrilla racemiflora, Ilex glabra, and Vaccinium spp, are associated with peat-based substrates (Bennett and Nelson 1991). Herbaceous or depression meadow bays, dominated by a mixture of wetland forbs, grasses, and sedges, are often associated with a history of disturbance (Bennett and Nelson 1991), variable hydrology, and deep sandy soils (DeSteven and Toner 1997).

Vegetation patterns within bays are related to hydrology (Sharitz and Gresham 1998). Vegetation along the hydrologic gradient from bay center to the margins in pond-like open-water and depression meadow bays is often in zones. That is, the distributions of dominant species are discrete, or discontinuous. Floating-leaved aquatic plants such as Nymphaea odorata and Brasenia schreberi occur toward the center and emergents such as Panicum hemitomon and Leersia hexandra occur toward the margin (Kelley and Batson 1955, Kirkman 1992, Poiani and Dixon 1995, Sharitz and Gresham 1998).

Vegetation patterns within and among Carolina bays reflect successive filters on propagule bank composition, recruitment, and plant survival. For example, Poiani and Dixon (1995) report differences in seed bank composition that may reflect differences in flooding regime among shrubby and herbaceous bays. As has been shown in other wetlands with fluctuating hydrology (van der Valk and
Davis 1976, but see Leck and Graveline 1979, Parker and Leck 1985), Carolina bay seed banks can be richer than the herbaceous vegetation and propagules tend to be more continuously distributed along the hydrological gradient (Kirkman and Sharitz 1994, Poiani and Dixon 1995). Hydrology can interact with plant emergence or seed germination requirements to filter propagule bank expression, although surrounding landscape (Poiani and Dixon 1995), soil disturbance (Kirkman and Sharitz 1994), and fire history (Kirkman and Sharitz 1994) can additionally affect propagule bank composition and expression in Carolina bays.

The relationship between hydrology and propagule bank expression in Carolina bay vegetation has been examined primarily for the seed component (Kirkman and Sharitz 1994, Poiani and Dixon 1995) and has not been explored over hydrological variation within and among bays. Fluctuating water level can be associated with unzoned seed banks and vegetation dominated by annuals and small perennial species that recruit from the seed bank (van der Valk 1981, Gerritsen and Greening 1989, Kirkman and Sharitz 1994, Poiani and Dixon 1995). When or where drying events are rare in wetlands, longlived perennial clonal species tend to dominate (Boutin and Keddy 1993), recruitment from the seedbank is low (Shipley and Parent 1991), and the seed bank can have low correlation with vegetation (van der Valk 1981, Poiani and Dixon 1995). Research is needed to compare expression of the entire propagule bank (seeds + rhizomes) and extant vegetation over hydrological variation within and among isolated wetlands such as bays. Such research can inform models of wetland vegetation organization and dynamics, which are generally applied to compare vegetation of wetlands with stable vs. fluctuating hydrology or to explain vegetation response to drawdown (e.g., van der Valk 1981).

We examined the relationships among hydrology, recruitment from the propagule bank, and extant vegetation over one season in six herbaceous depression meadow Carolina bays that differ in hydroperiod and basin shape. The approach was experimental; sediment cores were removed from locations around each bay at increasing distance from bay center and subjected to three hydrology treatments in an outdoor mesocosm array: flooded, dry down, or moist soil. We compared composition of vegetation that developed from each core (core vegetation) among hydrology treatments and with extant vegetation in the bays (bay vegetation) at each core sampling distance to test the general hypothesis that hydrology filters recruitment and vegetation composition within and 
Table 1. Characteristics of six herbaceous Carolina bays in Aiken and Allendale counties, South Carolina, USA.

\begin{tabular}{cccc}
\hline Bay & $\begin{array}{c}\text { Area } \\
\text { (ha) }\end{array}$ & $\begin{array}{c}\text { Surrounding } \\
\text { Landscape }\end{array}$ & Soil Type \\
31 (Dry) & 7.27 & Terrace & Williman \\
66 (Mona) & 11.65 & Sandhills & Ogeechee \\
67 (Woodward) & 9.49 & Sandhills & Ogeechee \\
77 (Craig's Pond) & 78.20 & Sandhills & Ogeechee \\
78 (Sarracenia) & 4.48 & Sandhills & Ogeechee \\
176 (Ellenton) & 12.14 & Terrace & Rutledge \\
\hline
\end{tabular}

among bays. The following specific hypotheses, derived from the general hypothesis, were tested:

Among bays,

- flashy bays, which have broader zones of fluctuating hydrology than more pond-like bays, will have more recruitment from the propagule bank and support vegetation that is more species-rich.;

- the propagule bank (core vegetation) and extant vegetation of flashy bays is less zoned than that of pond-like bays; i.e., species are more continuously distributed among sampling locations along the flooding gradient from bay centers to the margins.

Within bays,

- the proportion of obligate wetland species decreases and the proportion of facultative wetland and upland species in core and bay vegetation increases with distance from bay center toward margin;

- recruitment from the seedbank and species richness of core and bay vegetation increase from center toward margin as depth and duration of flooding decrease.

Among water level treatments,

- recruitment from the seedbank and species richness of core vegetation increase from flooded hydrology to fluctuating hydrology and moist soil treatments;

- the water level treatment that most closely matches local hydrology will result in greatest similarity between the plant community from sediment cores (core vegetation) and extant bay vegetation.

\section{Methods}

Six herbaceous, or depression meadow, Carolina bays on the Savannah River Site (SRS) near Aiken, SC were selected (Table 1). All are "set aside" from management and designated for non-manipulative research. Four of the bays are in the sandhills region of the SRS, and are underlain by deep sands. Two are on a terrace of the Savannah River.

To sample sediment in each bay, transects were established N, S, E, and W from bay center (the deepest point) to the margin (Fig. 1). Differences in hydrology and basin morphology among bays and among the sampling transects within each bay were considered in establishing sampling locations along each transect. Hydrological monitoring data, gathered biweekly from May, 1989 through August, 1993 from a staff gauge in the middle, i.e., the deepest point, of each bay, were used to determine the margin position along each transect at which the bay was full $(100 \%$, the maximum water level during the monitoring period). The $100 \%$ water level height on the staff gauge was projected N, S, E, and $\mathrm{W}$ to the margins to establish a transect starting point. A sediment sampling point was established along each transect toward the center at distances $(\mathrm{d} 75-\mathrm{d} 10)$ that represent $75 \%, 50 \%, 25 \%$, and $10 \%$ of full basin water level (Fig. 1). These procedures allowed us to relate sediment sampling to hydrology within and among bays. For example, during times when a bay was half full, the four $50 \%$ sampling locations would be at the water edge and the $75 \%$ locations would be exposed.

Eighteen sediment cores $8 \mathrm{~cm}$ diameter and $10 \mathrm{~cm}$ deep were removed from within a $1 \mathrm{~m}$ radius around each sampling point during late winter 1994-1995 when the bays were maximally full for the season. Cores were returned to the lab, and each set of 18 was divided into three sets of six cores. Each of the three sets was thoroughly mixed and spread over $8 \mathrm{~cm}$ sand in a plastic bin $(25 \mathrm{~cm}$ x $30 \mathrm{~cm} \times 12 \mathrm{~cm}$ deep) in late February. The three bins from each sampling point were allocated among three hydrology treatments: flooded (FL), midsummer drawdown (DD), or moist soil (MS). Hydrology treatments were es- 


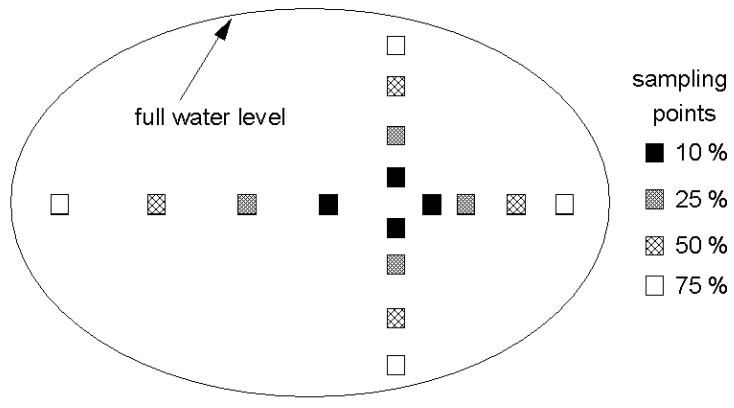

Figure 1. Location of sediment core sampling points at $10 \%, 25 \%, 50 \%$, and $75 \%$ full water level in each cardinal direction within a Carolina bay. Points are shown unequally spaced; the location of each point differed among transects and bays due to basin shape variation.

tablished by placing the sediment bin inside a larger bin ( $36 \mathrm{~cm} \times 51 \mathrm{~cm} \times 22 \mathrm{~cm}$ deep). Holes were drilled in the sides of the outer bin, and it was flooded to provide $10 \mathrm{~cm}$ (FL and DD treatments) or $0 \mathrm{~cm}$ (MS treatment) water cover. Midsummer drawdown in early July was accomplished by drilling holes in the outer bins to drop the water level from $10 \mathrm{~cm}$ to $0 \mathrm{~cm}$ cover.

The experimental design yielded 4 replicate bins in each hydrology treatment at each sampling distance within a bay, for a total of 288 bins (4 directions $\mathrm{x} 4$ locations/bay x 3 hydrology treatments $x 6$ bays). The experiment was conducted in an outdoor "botplot." To raise bins off the ground, two rows of wooden pallets were laid down and three bins, one of each hydrology treatment, were allocated to a pallet. Three sets of "blank" bins, which lacked propagule banks, were established for each hydrology treatment and placed at locations through the experimental bin array to monitor seed input and establishment from surrounding vegetation.

We did not harvest emerging plants, but allowed vegetation to develop through the growing season. Cover, to the nearest $1 \%$, was estimated by species in each bin in late July.

The plant community at each field sampling point was sampled in July. At each point two $1 \mathrm{~m} \mathrm{x} 1 \mathrm{~m}$ quadrats were established just outside the $1 \mathrm{~m}$ diameter sediment sampling area. Cover of each species was estimated to the nearest $1 \%$ in each of the 192 quadrats.

Hydrology in each bay was monitored from March through December, 1995, by biweekly readings of the staff gauge in each bay. The frequency (number of sampling dates a point was underwater divided by total number of sampling dates) and depth of flooding at each sampling point were calculated for this monitoring period to assess bay flashiness during the season.

\section{Data analysis}

Bins and quadrats were considered experimental units replicated over N, S, E, and W transects at each sampling distance within bays. Species richness (number of taxa per bin or quadrat) was compared by analysis of variance for both bin (core) and bay data. For core vegetation, three non-nested main effects: hydrology treatments $(n=3)$, sampling distances $(n=4)$, and bays $(n=6)$, and all twoway interactions were tested. For bay vegetation, two non-nested main effects, sampling distances $(n=4)$ and bays $(n=6)$ and their interactions were tested. Means within main effects were compared by Bonferroni t-tests. Non-significant $(p>0.10)$ main effects and interactions are not reported. Species richness data were arc-sin square-root transformed to conform to normality.

Stratified randomization tests (T. Philippi, unpublished) were developed to analyze hydrology and location (distance from center, bay) effects on sediment core communities and location (distance from center, bay) effects on bay vegetation. Cover estimates for each sample were square-root transformed to down-weight dominant taxa; transformed cover was then used to calculate Bray-Curtis dissimilarity among bin or quadrat samples. We tested the significance of each comparison described below using a Wilcoxon or Kruskal-Wallis test, with the $p$ value for each test based on 10,000 randomization trials, to determine if differences were greater than would be expected if samples were randomly assigned to treatments. To compare hydrology treatment effects on bin composition, dissimilarities were compared between vs. within hydrology treatments stratified by bay and sampling distance. To compare sampling distance location effects on bin composition, dissimilarities were compared between vs. within sampling distances stratified by hydrology treatment and bay. To compare bay effects on bin composition, dissimilarities were compared between vs. within bays stratified by hydrology treatment and sampling distance. To compare distance effects on vegetation within bays, dissimilarities were compared between vs. within sampling point distances stratified by bay. Finally, to compare bay effects on vegetation, dissimilarities were compared between vs. within bays stratified by sampling point distance. For effects such as hydrology treatments with more than two levels, both full and pairwise comparisons were run.

Similarity of bin and extant bay vegetation from each sampling point, calculated by Jaccard's presence/absence 
Table 2. Coefficient of variation of bay water level (CV), flooding frequency and mean water depth at each sampling distance (d10 - d75) from bay center, in six Carolina bays from March to December, 1995.

\begin{tabular}{lcccccc}
\hline & \multicolumn{7}{c}{ Bay } & & \\
\cline { 2 - 7 } CV & 31 & 176 & 77 & 78 & 66 & 67 \\
Flooding Frequency & 10.8 & 24.1 & 28.8 & 30.9 & 33.5 & $286.8^{*}$ \\
d10 & 1.00 & 1.00 & 0.96 & 1.00 & 1.00 & 0.36 \\
d25 & 1.00 & 1.00 & 0.96 & 1.00 & 1.00 & 0.18 \\
d50 & 1.00 & 1.00 & 0.82 & 1.00 & 0.91 & 0.07 \\
d75 & 0.52 & 0.00 & 0.04 & 0.21 & 0.03 & 0.00 \\
Water Depth (cm) & & & & & & \\
Maximum & 148 & 163 & 89 & 105 & 170 & 134 \\
d10 & 111 & 71 & 42 & 68 & 76 & 30 \\
d25 & 89 & 49 & 30 & 53 & 50 & 11 \\
d50 & 52 & 10 & 11 & 28 & 11 & 3 \\
d75 & 17 & 0 & 1 & 7 & 2 & 0 \\
\hline
\end{tabular}

*bay dried completely; CV does not reliably estimate water level variation

index, was compared using Kruskal-Wallis tests. Bin and bay vegetation similarity was compared 1 ) among bays at each sampling distance and 2) among distances within each bay with hydrology treatments combined. Bin and bay similarity was also compared among hydrology treatments at each distance with bays combined to determine if the hydrology treatment that most closely matched actual bay hydrology at that distance produced more similar vegetation than the other hydrology treatments.

Plots of vegetation similarity or dissimilarity results show the range (minimum to maximum), $25^{\text {th }}$ and $75^{\text {th }}$ quantiles, and median values. We utilized Statistical Analysis System (SAS 7.0) for all analyses.

\section{Results}

\section{Bay hydrology}

Hydrology of the six Carolina bays differed among bays during the 1995 growing season (Table 2). Bay 31 was the most pond-like, i.e., it showed the least variation in water level. Bay 67 was the flashiest, i.e., it showed the greatest variation in water level through the season. The remaining four bays were between these extremes, and formed a mild gradient from more- to less- pond-like (Table 2).

The zone of water level fluctuation within each bay reflected whole-bay hydrology and basin morphology (Table 2). In pond-like Bay 31, water level fluctuated above the $\mathrm{d} 50$ distance; $\mathrm{d} 75$ was flooded with $17 \mathrm{~cm}$ water depth more than $50 \%$ of observation period. In contrast, water level in Bay 67 fluctuated throughout all distances from the center; $\mathrm{d} 75$ was never inundated (Table 2).

\section{Extant vegetation}

Vegetation richness differed among bays ( $\mathrm{df}=5$, mean square $=8.83, \mathrm{~F}=3.54, \mathrm{p}=0.006$ ) and tended to differ with distance from bay centers toward their margins $(\mathrm{df}=3$, mean square $=5.69, \mathrm{~F}=2.2 .8, \mathrm{p}=0.086$ [Fig. 2] $)$. A significant interaction between bays and sampling locations $(\mathrm{df}=15$, mean square $=5.17, \mathrm{p}=0.02)$ indicated different patterns of richness with distance from center over the bays. Species richness among bays was related to bay flashiness and, apparently, basin morphology. The most flashy bay, 67, had the highest richness, and the most pond-like bay, 31, had significantly lower richness; the remaining four bays were intermediate. Bay 66 , in which water level fluctuated within a deep central basin and long shallow margin, had no vegetation in bay center and lowest overall richness of the four intermediate bays. Richness within bays tended to increase from center locations (d10, d25), which were continuously flooded in most bays, toward margin locations (d50, d75) where water level fluctuated (Fig. 2). In general, greater richness was associated with the zone of water fluctuation in each bay (Fig. 2).

Patterns of bay vegetation composition were also related to location within bays. Bay vegetation dissimilarity, calculated among all sampling plots at each sampling distance in each bay, increased from center to edge in most bays (Fig. 3). Vegetation was weakly to strongly zoned with distance from bay center. Compared among sampling distances stratified by bay, vegetation dissimi- 
Figure 2. Species richness within and among bays. Different letters denote significant differences among sampling distances from bay center $(\mathrm{d} 10-\mathrm{d} 75)$ or among bays. Bays are ordered from least (Bay 31) to most (Bay 67) flashy.

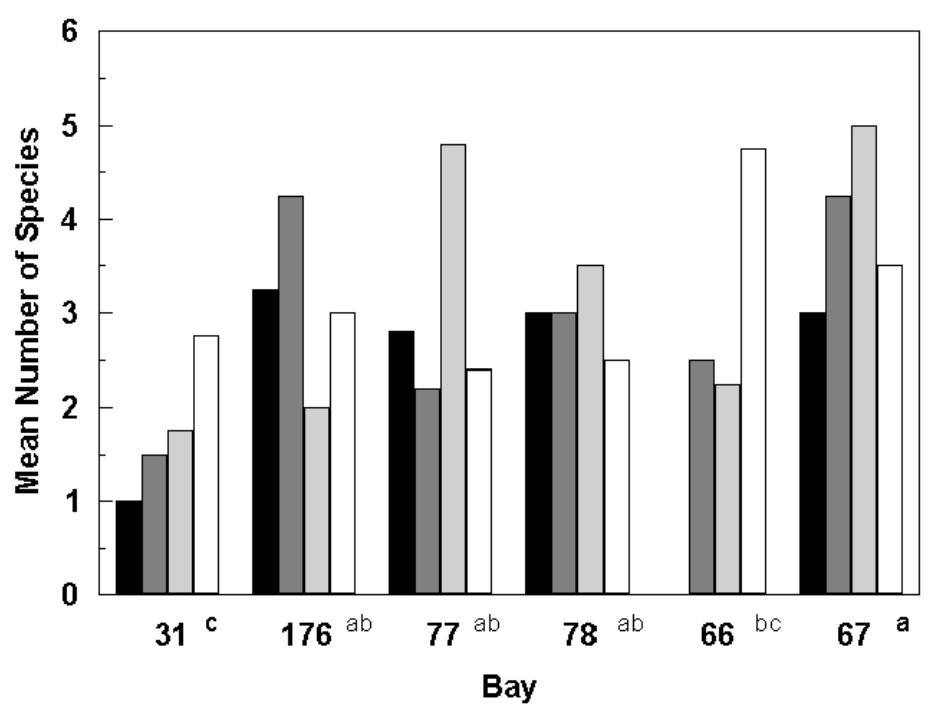

Figure 3. Median bay vegetation dissimilarity among plots at each sampling distance within bays. Sampling distances are ordered from bay interior (d10) to margin (d75); bays are ordered from least (Bay 31) to most flashy.

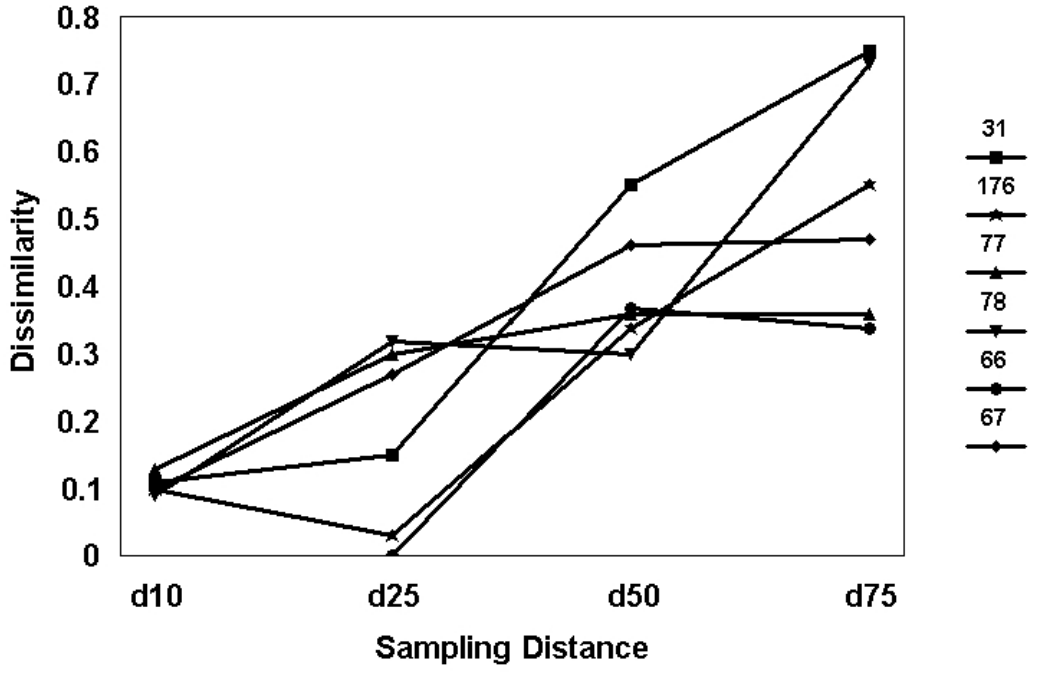

larity was greater among than within all distance pairs ( $p$ $<0.0001$ for all distance pairs; Fig. 4). The degree of difference apparently was related to basin morphology and bay flashiness. In pond-like Bay 31 and deep-centered Bay 66, more than half of all between-distance plots were totally dissimilar (median dissimilarity $=1$; Fig. 4), which suggests stronger zonation or greater species turnover in bay vegetation with distance from center in these bays. In flashy Bay 67, between-distance dissimilarity was low and within-distance dissimilarity was high relative to the other bays (Fig. 4), which suggests the least zonation of bay vegetation with distance in this bay. Bay vegetation was more dissimilar between than within bays with comparisons stratified by sampling distance $(p=0.0001)$.

Plant distributions among sampling distances within bays and among bays reflected bay hydrology and basin morphology (Fig. 5). The deep center (d10) of Bay 66 lacked vegetation. In all bays except the most flashy, Bay 67 , bay vegetation graded from obligate wetland plants to a mix of obligate wetland and facultative (facultative, facultative wetland, facultative upland) (Sabine, 1992) plants with distance from bay center to margin (Fig. 5). Only obligate wetland plants, primarily floating-leaved Nymphaea odorata, Brasenia schreberi, and Utricularia spp., and emergents Panicum hemitomon and Leersia hexandra, occupied central locations (d10, d20). At d50, an emergent community comprised primarily of obligate wetland plants such as Panicum hemitomon and the herb Lachnanthes caroliniana was found. Facultative plants, including Smilax spp. and Ilex spp., comprised a greater proportion of cover at d75 (Fig. 5). Bay 67 lacked floating-leaved aquatic plants. Vegetation at the center was 
dominated by obligate emergents; these declined as facultative herbs and woody species increased toward the bay margins (Fig. 5).

\section{Propagule bank response}

Species richness of core vegetation from the propagule bank differed significantly among hydrology treatments $(\mathrm{df}=2 ;$ mean square $=170.85 ; \mathrm{F}=46.32 ; p=$ $0.0001)$; richness was greatest with moist soil, intermediate with drawdown, and least with flooding (Fig. 6). Richness did not differ among sediment sampling distances within bays $(\mathrm{df}=3$; mean square $=3.62 ; \mathrm{F}=0.98 ; p=$ $0.40)$. Richness of propagule core vegetation differed among bays $(\mathrm{df}=5$; mean square $=17.29 ; \mathrm{F}=4.69 ; p=$ 0.0004 ), but did not correspond to bay hydrology. Bay

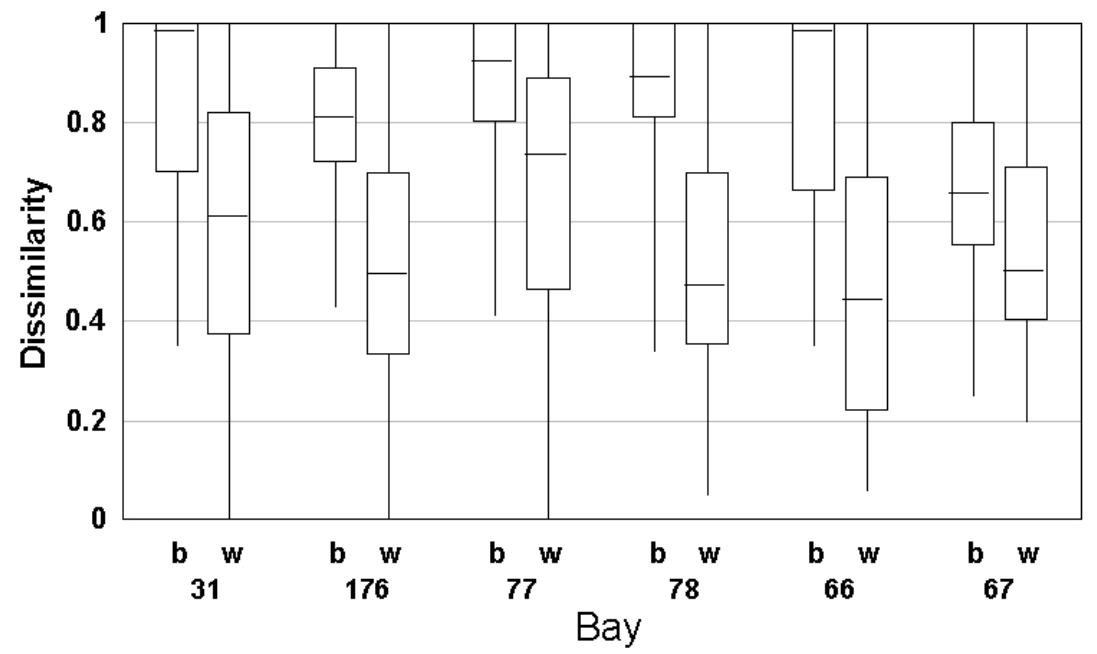

Figure 4. Vegetation dissimilarity between (b) and within (w) sampling distances in each bay. Dissimilarities were calculated among all plots within and between all pairs of sampling distances in each bay.

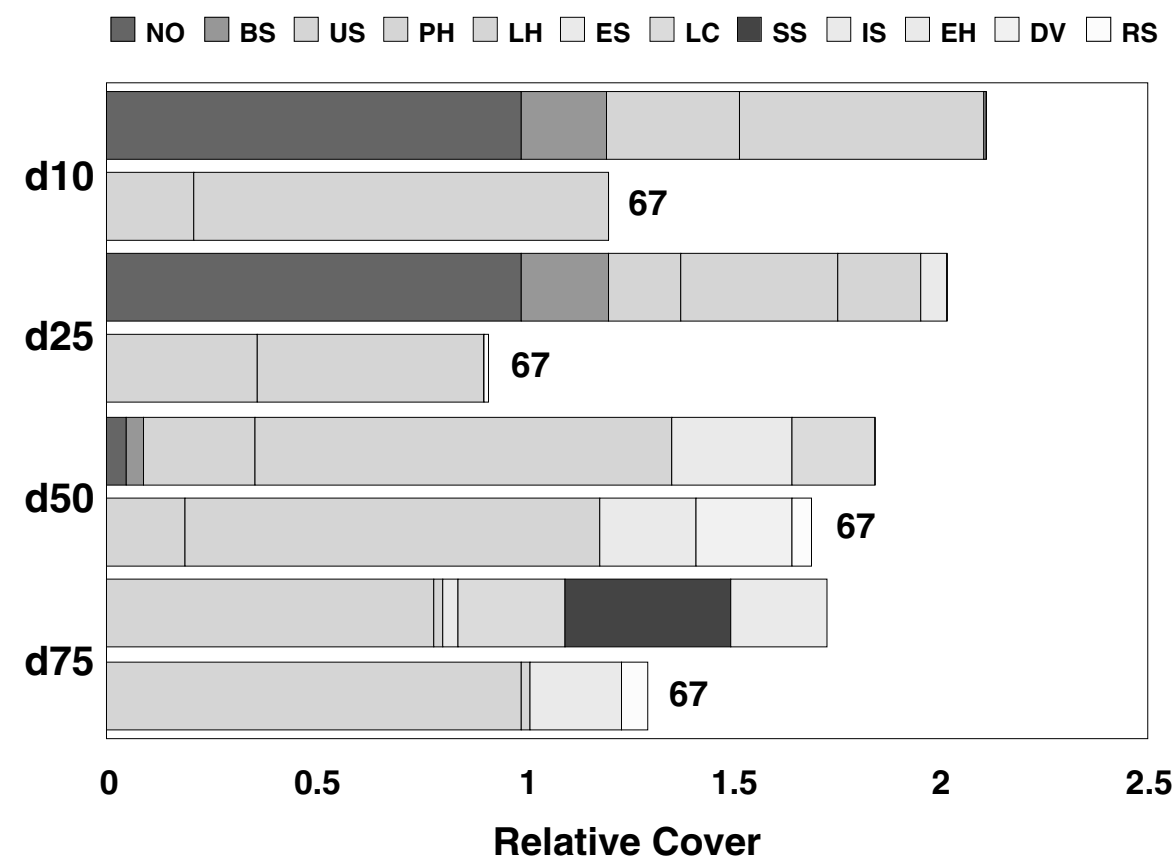

Figure 5. Relative cover of dominant taxa at distances (d10, d25, d50, and d75) from the center of the flashy Bay 67 and the other, less flashy bays (Bays 31, 66, 77, 78, 176). At each distance, cover for each taxon is relative to that of the most abundant taxon. Obligate wetland plants include floating-leaved plants Nymphaea odorata (NO), Utricularia spp. (US), and Brasenia schreberi (BS); emergents Panicum hemitomon (PH), Leersia hexandra (LH), and Eleocharis spp. (ES); and the herb Lacnanthes caroliniana (LC). Facultative species include Erectites hieracifolia (EH), Ilex spp. (IS), Smilax spp. (SS), Rubus spp., and Diospyros virginiana (DV). 
Figure 6. Species richness from bay sediment samples subjected to flooded, midsummer drawdown, or moist soil conditions. Different letters denote significant $(p<0.05)$ difference in richness among bays and hydrology treatments. Richness did not differ significantly among sampling distances.
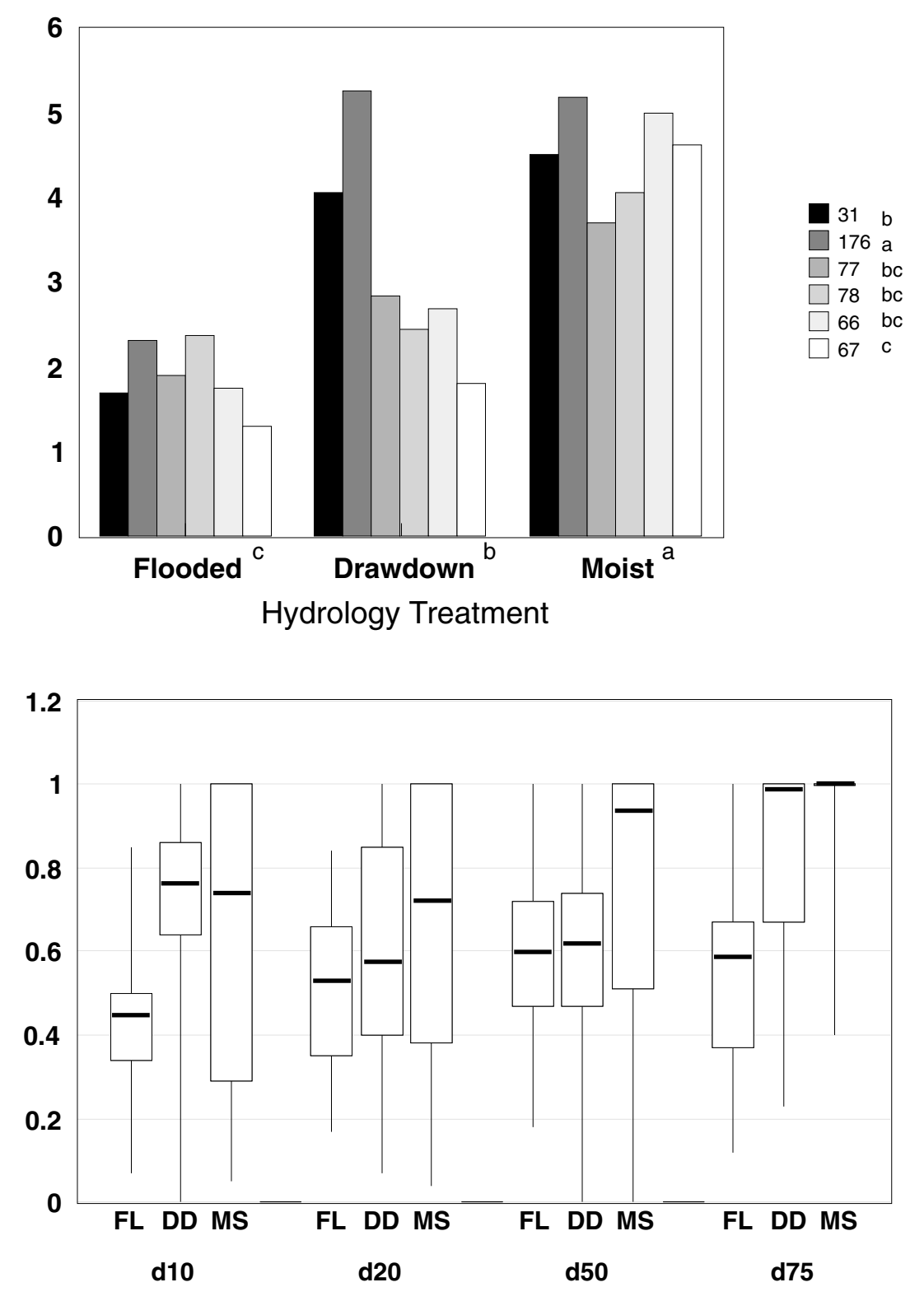

Figure 7. Dissimilarity of vegetation from sediment cores taken from distances (d10 d75) from the centers of six Carolina bays and subjected to flooded (FL), drawdown (DD), or moist soil (MS) conditions. Dissimilarity was calculated among cores at each sampling distance subjected to the same hydrology treatment with bays pooled.
176 had greatest core vegetation richness; flashy Bay 67 had least richness; and pond-like Bay 31 had intermediate richness that did not differ from the remaining three bays (Fig. 6). Two-way interactions among the main effects were not significant.

Water level treatment, sampling distance within the bay, and bay origin all influenced vegetation that developed from the sediment cores. Bin communities differed more among than within hydrology treatments when stratified by bay and sampling distance and compared to random expectations $(\mathrm{KW}=30.1882, \mathrm{p}=0.0001$; median dissimilarity $=0.77$ between, 0.62 within). At each sam- pling distance, core vegetation tended to be more similar in the continuously flooded treatment and least similar in the moist soil treatment (Fig. 7). Flooded bins and bins that were drawn down were dominated by a mixture of floating-leaved and emergent wetland plants, including Utricularia spp., Eleocharis spp., and Panicum hemitomon (Fig. 8). Bins with continuously moist soil also contained these taxa, but had greater cover of three additional emergents, Cyperus spp., Carex spp., and Rhynchospora spp. Some species common in bay vegetation, including floating-leaved perennials Nymphaea odorata and Brasenia schreberi (Fig. 5), occurred only infrequently in vegetation from the sediment cores. 

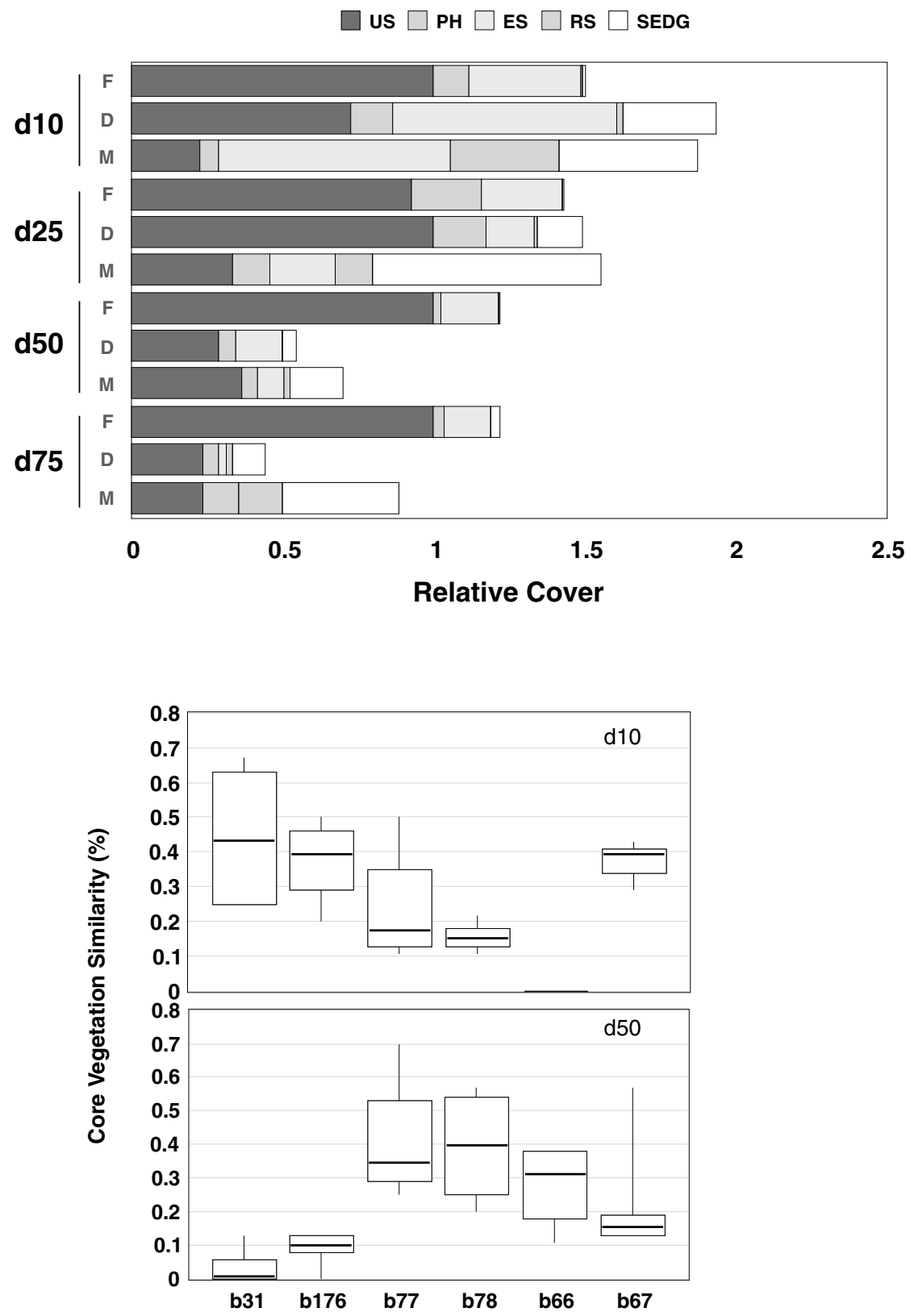

Figure 8. Relative cover of taxa in vegetation from sediment cores taken from distances (d10 - d75) from bay centers and subjected to flooded (F), drawdown (D), or moist soil (M) conditions. At each hydrology treatment and distance combination, cover is relative to the taxon with the greatest cover. US $=$ Utricularia spp.; $\mathrm{PH}=$ Panicum hemitomon; $\mathrm{ES}=$ Eleocharis spp.; RS =

Rhynchospora spp.; SEDG = combined cover of Cyperus spp. and Carex spp.

Figure 9. Similarity of sediment core and bay vegetation near (d10) and away (d50) from the centers of six Carolina bays. Bays are ordered from most pond-like (Bay 31) to most flashy (Bay 67).
Bin communities from sediment cores differed more among than within sampling distances $(\mathrm{KW}=37.74, \mathrm{p}=$ 0.0001 ) when stratified by bay and water level treatment (Fig. 7). Bin vegetation became more dissimilar with core distance from bay center, and margin (d75) cores produced the most divergent communities in each water level treatment (Fig. 7).

Bin communities from the sediment cores also differed among bays $(\mathrm{KW}=168.04, p=0.0001)$ when stratified by sampling distance and water level treatment. Core vegetation differed more among than within all pairs of bays, but was only marginally different between the two most pond-like bays (Bay 31 and Bay 176; median dissimilarity $=0.57 ; \mathrm{KW}=1.56, p=0.05$ ). In general, core vegetation dissimilarity was greater between bay pairs with the most contrasting hydrology (e.g., Bay 31 and Bay 67 ; median dissimilarity $=1 ; \mathrm{KW}=57.28 ; p=0.0001$ ) and less between bay pairs with similar hydrology (e.g., Bay 31 and Bay 176).

\section{Propagule bank - extant vegetation comparisons}

Vegetation from the sediment cores (core vegetation) was compared to bay vegetation using presence-absence based similarity. With water level treatments and sam- 
pling locations pooled, the similarity of core and bay vegetation did not differ among bays (median $=0.2, \chi^{2}=$ $3.2, p=0.67$ ). With each sampling distance considered separately, core and bay vegetation similarity differed among bays at $\mathrm{d} 10\left(\chi^{2}=15.91, \mathrm{p}=0.007\right)$ and $\mathrm{d} 50\left(\chi^{2}=\right.$ $16.66, p=0.005)$ (Fig. 9). At d10, core and bay vegetation were most similar for the pond-like bays 31 and 176 and for the flashy Bay 67 (Fig. 9). At d50, core and bay vegetation were least similar for the pond-like bays and the flashy bay 67 (Fig. 9). Within bays, core and bay vegetation similarity differed among sampling points only in the most pond-like bay (Bay $\left.31, \chi^{2}=12.06, p=0.007\right)$. In this bay, core and bay vegetation were more similar at interior locations $\mathrm{d} 10$ and $\mathrm{d} 25$ (median similarity $=0.42$ and 0.58 , respectively) than at the more marginal locations $\mathrm{d} 50$ and $\mathrm{d} 75$ (median similarity $=0$ and 0.04 , respectively).

We calculated the similarity between bay vegetation at each sampling point in each bay and core vegetation from the corresponding location in each hydrology treatment. Although, with bays pooled, core and bay vegetation were most similar in the hydrology treatment that corresponded most closely with bay hydrology at each sampling distance, differences among hydrology treatments were only significant at $\mathrm{d} 75\left(\chi^{2}=10.06, \mathrm{p}=\right.$ $0.0065)$. At that sampling distance, core vegetation in the moist soil (MS) treatment tended to have more species in common with bay vegetation than did core vegetation in the other two hydrology treatments (Fig. 10).

\section{Discussion}

The interaction of basin morphology with precipitation and groundwater inputs (Schalles and Shure 1989, Lide et al. 1995), determined two components of seasonal hydrology in the six herbaceous Carolina bays: water depth and the extent of the fluctuating water zone. Shallow bays had "flashy" hydrology and broad fluctuating water zones; the flashiest (Bay 67) dried completely during summer. Bays with steeper slopes (e.g., Bay 31) were more pond-like with relatively narrow zones of fluctuating water and stable hydrology. These patterns of hydrological variation among the bays agree with previous observations and ongoing hydrological monitoring. Poiani and Dixon (1995) included Bays 31, 67, and 78 in their research on bay seedbanks. They categorized Bay 31 and Bay 78 as "wetter" and Bay 67 as "drier" in 1990; Bay 67 was dry when the seedbank was sampled. Hydrological monitoring at monthly intervals since 1995 (R. Lide, unpublished data) corroborates the hydrological pattern among the six bays, from pond-like Bay 31 , which has varied in water depth between 0.95 and $1.75 \mathrm{~m}$, to flashy Bay 67 , which was dry 36 of the 62 observation periods.

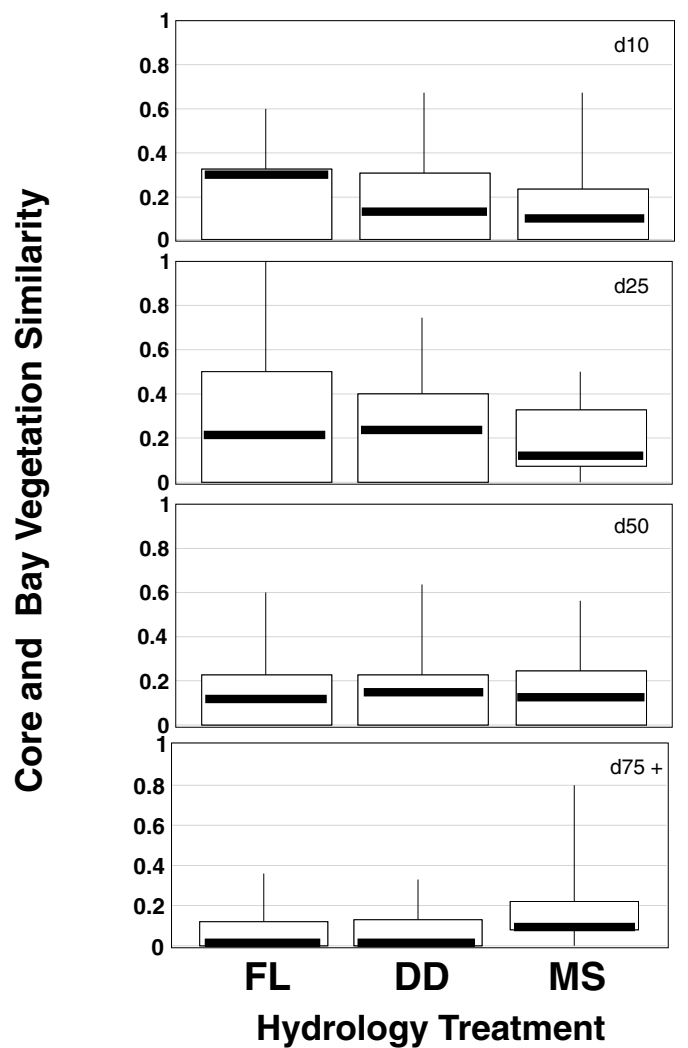

Figure 10. Similarity of vegetation from sediment cores subjected to flooded (FL), drawdown (DD), or moist soil (MS) hydrology treatment and extant bay vegetation at distances $(\mathrm{d} 10-\mathrm{d} 75)$ from bay centers.

Variation in species distributions, richness, and vegetation banding in response to hydrological patterns within and among the bays agreed with our specific hypotheses. Vegetation diversity and patterns within and among the bays reflected plant response to water depth and relative extent of the inundated, fluctuating, and exposed sediment zones during the season. Within bays, vegetation became richer and more dissimilar from bay centers toward the margins. The pattern of diversity and degree of dissimilarity over distances were influenced by width of the fluctuating water zone; this zone was associated with greatest richness within the bays. Among bays, vegetation richness varied with flashiness. Pond-like Bay 31 had a narrow species-rich fluctuating water zone, and lowest whole-bay species richness. In contrast, flashy Bay 67 had a broad fluctuating water zone and high whole-bay richness.

The degree to which vegetation was in bands, or zoned, with distance from bay center reflected species distributions and varied with whole-bay hydrology. The deep center of Bay 66 lacked vegetation. The most flashy 
bay (Bay 67) lacked floating-leaved aquatic plants and had greatest whole-bay species richness. In the remaining bays, species were distributed from obligate floatingleaved and emergent wetland plants such as Nymphaea odorata and Panicum hemitomon toward the center through a mix of obligate and facultative wetland plants toward the margins. Comparison of bay vegetation similarity among distances indicates strongest zonation in pond-like Bay 31 and deep-centered Bay 66, and least zonation in flashy Bay 67.

Vegetation patterns in response to hydrology within and among the six Carolina bays agree with patterns in other bays and wetlands. In nearby L-Lake, a reservoir with relatively stable hydrology, shoreline vegetation is zoned from a richer mix of upland and facultative wetlands plants at the waterline and on-shore, through emergents in shallow water, to a less rich band of clonal perennial submerged and floating-leaved plants in deeper water (Collins and Wein 1995). Species are often zoned in depression meadow Carolina bays (Kelley and Batson 1955, Bennett and Nelson 1991), which have been characterized as "ecotonal" between open water and dry land (Bennett and Nelson 1991). Poiani and Dixon (1995) subjectively identified three vegetation zones in pond-like Bay 31 (open water, Panicum, Cephalanthus), four in Bay 78 (open water, Panicum, Andropogon, Rhynchospora), and four in flashy Bay 67 (Panicum, Leersia, Andropogon, shortgrass). In Thunder Bay on the SRS, floatingleaved (Nymphaea odorata, Brasenia schreberi) and emergent (Panicum hemitomon, Eleocharis spp.) plants reached peak biomass at different depths (Schalles and Shure 1989).

Among wetlands generally, spatial organization and zonation of wetland vegetation appears to be related to steepness of the water depth gradient, which is affected by the interplay between hydrologic inputs, outputs, and basin morphology. Zonation in playa wetlands (Hoagland and Collins 1997) and glacial prairie marshes (Johnson et al. 1987) is most pronounced in larger and deeper basins. The water depth gradient is not, however, the only influence on wetland species distributions and zonation. Interspecific competition can modify species distributions and vegetation patterns (Grace 1990, Grace and Wetzel 1998). Other forces not usually encountered in bays, such as wave action or fetch (Keddy 1983, Rea et al. 1998) can shift species distributions to create species clusters or zonation. In bays, vegetation composition and pattern can be influenced by disturbances such as drought, fire, or soil disturbance (Kirkman and Sharitz 1994). Bay vegetation zones are dynamic; they can shift position or species composition over time in response to disturbances or seasonal rainfall patterns (Poiani and Dixon 1995, Kirkman 1992, Kirkman and Sharitz 1994). Our data suggest patterns of bay vegetation and propagule bank expression are filtered each year by the pattern of inundated, fluctuating, and moist soil areas that result from hydrological variation within the bay.

Comparisons of propagule bank expression among the hydrological treatments and with bay vegetation patterns generally agree with our specific hypotheses and support the thesis that differences among species in germination, emergence, and survival response to inundation underlies wetland vegetation organization and dynamics (van der Valk 1981, Blom and Voesnek 1996, Grace and Wetzel 1998). Vegetation from sediment cores, and the relationship of core (bin) and extant bay vegetation, revealed plant responses both to the local pattern of inundation (hydrology treatment or among sites within a bay) and to differences in whole-bay hydrology among bays. Bin communities were relatively dissimilar between bays of contrasting hydrology and most similar between bays of similar hydrology. The flooding treatment promoted convergence on obligate wetland taxa. Species richness decreased and similarity among bin communities increased as degree of inundation increased (continuously flooded midsummer drawdown moist soil hydrology treatment). In wetlands generally, few species germinate or survive under water (Smith and Kadlec 1983). With extended inundation, and in deeper water, recruitment from seeds is limited; vegetation is typically dominated by clonal perennial aquatic floating-leaved and emergent plants (van der Valk 1981, Gerritsen and Greening 1989, Kirkman and Sharitz 1994).

In contrast to our hypothesis, we did not find that similarity between bin communities and bay vegetation was greatest when water level treatment most closely matched local hydrology. With hydrology treatments pooled and the data considered by sampling distance, bin-bay similarity at bay centers (d10) was greatest for both pond-like bays (Bay 31, 176), where long inundated communities converged on obligate wetland taxa, and the flashy Bay 67 , in which the aquatic community was absent. At d50, bin and bay communities were most dissimilar in flashy Bay 67, but were also dissimilar in the pond-like bays, perhaps because this location was the periphery of the inundated zone of these bays. In wetlands generally, shoreline regions above the waterline, or exposed by drawdown, disturbance, or fluctuating water levels, support a mix of obligate and facultative wetland plants and upland species that recruit from the seedbank (van der Valk 1981). In our research, sediment core (bin) and bay vegetation, and bin-bay similarity patterns reflected greater 
propagule bank expression, increased richness, and low similarity with local (hydrology treatment or within-bay) or whole-bay exposure.

The interaction of hydrology with propagule bank expression and plant species survival has been examined primarily to understand differences in vegetation patterns between wetlands with fluctuating water levels and those with stable hydrology or to examine vegetation dynamics in response to drawdown (van der Valk 1981, van der Valk and Davis, 1976, 1978). Results of our research can be used to more explicitly explore the relationship between patterns of hydrological variation and seasonal vegetation organization within and among wetlands with fluctuating hydrology. In such wetlands, in the absence of influences such as drought, fire, or soil disturbance, basin shape combines with the amplitude and frequency of water level variation to determine the seasonal water depth profile and width of the fluctuating water zone (Keddy 2000). Species sort along the shoreline by drought and flooding tolerances, tempered by competition (Grace and Wetzel 1998, Keddy 2000). Recruitment from the propagule bank and subsequent plant survival in response to the relative extent of unflooded, fluctuating, and flooded zones (and water depth) determines composition and distribution of plants from wetland margin to interior and influences community-level attributes such as diversity, vegetation zonation, and wetland aspect.

Our research suggests that vegetation and propagule banks in wetlands with steep basins and more stable hydrology have greater zonation along the flooding gradient. In contrast, fluctuating hydrology, typical of more shallow basins, causes a periodic "reshuffling" of the vegetation, and produces more gradual changes in species composition along the flooding gradient (Sharitz and Gresham 1998). Vegetation in these systems tends to be unzoned and more gradient-like. These scenarios represent two extremes of wetland organization; between these extremes, vegetation can exhibit both patch-like and gradient-like characteristics in response to the pattern of hydrological variation.

Acknowledgments: This research was partially funded by a grant from the SREL Setaside program. Additional funding was by Financial Assistance Award Number DE-FC09-96SR18546 between the U.S. Dept. of Energy and the Univ. of Georgia. We thank Emily Cantonwine, Teresa Hock, and Stephanie Guisti for technical assistance.

\section{References}

Bauder, E. T. 1989. Drought stress and competition effects on the local distribution of Pogogyne abramsii. Ecology 70:10831089 .

Bennett, S. H. and J. B. Nelson. 1991. Distribution and status of Carolina bays in South Carolina. Nongame and Heritage Trust
Publications No. 1. South Carolina Wildlife and Marine Resources Department, Columbia SC.

Bertness, M. D. and S. M. Yeh. 1994. Cooperative and competitive interactions in the recruitment of marsh elders. Ecology 75:2416-2429.

Blom, C. W. P. M. and L. A. C. J. Voesenek. 1996. Flooding: the survival strategies of plants. TREE 11:290-296.

Boutin, C. and P. A. Keddy. 1993. A functional classification of wetland plants. J. Veg. Sci. 4:313-348.

Brinson, M. M. 1993. A hydrogeomorphic classification for wetlands. Wetlands Research Program Technical Report WRP-DE4. U. S. Army Corps of Engineers Waterways Experiment Station.

Collins, B. S. and G. R. Wein. 1995. Seed bank and vegetation of a constructed reservoir. Wetlands 15:374-385.

De Steven, D. 1994. Patterns of vegetation diversity among Carolina bays and depression wetlands on the Savannah River Site, South Carolina. Unpub. Report. 35 pp.

De Steven, D. and M. Toner. 1997. Gradient analysis and classification of Carolina bay vegetation: a framework for bay wetlands conservation and restoration. Unpub. Report for U.S.D.A. Forest Service. $53 \mathrm{pp}$.

Gerritsen, J. and H. S. Greening. 1989. Marsh seed banks of the Okefenokee swamp: effects of hydrologic regime and nutrients. Ecology 70:750-763.

Grace, J. B. 1990. On the relationship between plant traits and competitive ability. In: J. B. Grace and D. Tilman (eds), Perspectives on Plant Competition. Academic Press, San Diego, CA., pp. 5165.

Grace, J. B. and R. G. Wetzel. 1998. Long-term dynamics of Typha populations. Aquatic Bot. 61:137-146.

Hacker, S. D. and M. D. Bertness. 1999. Experimental evidence for factors maintaining plant species diversity in a New England salt marsh. Ecology 80:2064-2073.

Hoagland, B. W. and S. L. Collins. 1997. Heterogeneity in shortgrass prairie vegetation: the role of playa lakes. J. Veg. Sci. 8:277-286.

Johnson, W. C., T. L. Sharik, R. A. Mayes, and E. P. Smith. 1987. Nature and cause of zonation discreteness around glacial prairie marshes. Can. J. Bot. 65:1622-1632.

Keddy, P. A. 1983. Shoreline vegetation in Axe Lake, Ontario: effects of exposure on zonation patterns. Ecology 64:331-344.

Keddy, P. A. 2000. Wetland Ecology: Principles and Conservation. Cambridge University Press. Cambridge, UK.

Keddy, P. A. and P. MacLellan. 1990. Centrifugal organization in forests. Oikos 59:75-84.

Keddy, P. A. and A. A. Reznicek. 1982. The role of seed banks in the persistence of Ontario's Coastal Plain flora. Amer. J. Bot. 69:1322.

Kelley, W. R. and W. T. Batson. 1955. An ecological study of the land plants and cold-blooded vertebrates of the Savannah River Project area. Part VI. Conspicuous vegetational zonation in a ACarolina bay.@University of South Carolina Publication, Biology Series III, 1.

Keough, J., G. R. Guntenspergen, and J. Grace. 1989. Vegetation and hydrologic characteristics of Carolina bays. Unpub. Report for the Savannah River Ecology Laboratory, SRS.

Kirkman, L. K., 1992. Cyclical Vegetation Dynamics in Carolina Bay Wetlands. PhD Thesis, University of Georgia. Athens, GA.

Kirkman, L. K., R. F. Lide, G. R. Wein, and R. R. Sharitz. 1996. Vegetation changes and land-use legacies of depression wet- 
lands of the western coastal plain of South Carolina: 1951-1992. Wetlands 16:564-576.

Kirkman, L. K. and R. R. Sharitz. 1994. Vegetation disturbance and maintenance of diversity in intermittently flooded Carolina Bays in South Carolina. Ecol. Applications 4:177-188.

Leck, M. A., and K. J. Graveline. 1979. The seed bank of a freshwater tidal marsh. Amer. J. Bot. 66:1006-1015.

Leck, M. A. and R. L. Simpson. 1994. Tidal freshwater wetland zonation: seed and seedling dynamics. Aquatic Bot. 47:61-75.

Lenssen, J., F. Menting, W. van der Putten, and K. Blom. 1999. Control of plant species richness and zonation of functional groups along a freshwater flooding gradient. Oikos 86:523-534.

Lessman, J. M., I. A. Mendelssohn, M. W. Hester, and K. L. McKee. 1997. Population variation in growth response to flooding of three marsh grasses. Ecol. Engineering 8:31-47.

Lide, R. F., V. G. Meentemeyer, J. E. Pinder, L. M. Beatty. 1995. Hydrology of a Carolina Bay located on the upper Coastal-Plain of western South Carolina. Wetlands 15:47-57.

Mitsch, W. J. and J. G. Gosselink. 1993. Wetlands, $2^{\text {nd }}$ Edition. Van Nostrand Reinhold Co., New York, NY.

Parker, V. T. and M. A. Leck. 1985. Relationships of seed banks to plant distribution patterns in a freshwater tidal wetland. Amer. $J$. Bot. 72:161-174.

Poiani, K. A., and P. M. Dixon. 1995. Seed banks of Carolina bays: potential contributions from surrounding landscape vegetation. Amer. Midland Nat. 131:140-154.

Radford, A. E., H. E. Ahles and C. R. Bell. 1968. Manual of the Vascular Flora of the Carolinas. The University of North Carolina Press, Chapel Hill, NC.

Rea, T. E., D. J. Karapatakis, K. K. Guy, J. E. Pinder III, and H. E. Mackey Jr. 1998. The relative effects of water depth, fetch and other physical factors on the development of macrophytes in a small southeastern US pond. Aquatic Bot. 61:289-299.

SAS 7.0. Statistical Analysis System version 7.0. SAS Institute. Cary, $\mathrm{NC}$

Sabine, B. J. 1992. National List of Plant Species that Occur in Wetlands Region 2 - Southeast. Resource Management Group, Inc., Grand Haven, MI.

Schalles, J. F., R. R. Sharitz, J. W. Gibbons, G. J. Leversee, and J. N. Knox. 1989. Carolina Bays of the Savannah River Plant, Aiken,
South Carolina. SRO-NERP-18. Savannah River Ecology Laboratory, Aiken, SC.

Schalles, J. F. and D. J. Shure. 1989. Hydrology, community structure, and productivity patterns of a dystrophic Carolina bay wetland. Ecol. Monog. 59:365-385.

Semlitsch, R. D. 1986. Life history of the northern mole cricket, Neocurtilla hexadactyla (Orthoptera: Gryllotalpidae), utilizing Carolina-bay habitats. Annals of the Entomological Society of America 79:256-261.

Semlitsch, R.D., D. E. Scott, J. H. K. Pechmann, and J. W. Gibbons. 1996. Structure and dynamics of an amphibian community: evidence from a 16-year study of a natural pond. In: M. L. Cody and J. A. Smallwoods (eds.), Long-term Studies of Vertebrate Communities. Academic Press, San Diego, CA. pp. 217-248.

Sharitz, R. R. and J. W. Gibbons, J. W. 1982. The ecology of southeastern shrub bogs (pocosins) and Carolina bays: a community profile. U. S. Fish and Wildlife Service FWS/OBS-82/04.93.

Sharitz, R. R. and C. A. Gresham. 1998. Pocosins and Carolina Bays. In: Messina, M. G. and W. H. Conner (eds.), Southern Forested Wetlands Ecology and Management. CRC Press LLC, pp. 343378.

Shipley, B. and M. Parent. 1991. Germination responses of 64 wetland species in relation to seed size, minimum time to reproduction and seedling relative growth rate. Funct. Ecol. 5:111-118.

Smith, L. M. and J. A. Kadlec. 1983. Seed banks and their role during drawdown of a North American marsh. J. Appl. Ecol. 20:673684.

van der Valk, A. G. 1981. Succession in wetlands: a Gleasonian approach. Ecology 62:688-696.

van der Valk, A. G., and C. B. Davis. 1976. The seed banks of prairie glacial marshes. Can. J. Bot. 54:1832-1838.

van der Valk, A. G. and C. B. Davis. 1978. The role of seed banks in the vegetation dynamics of prairie glacial marshes. Ecology 59:322-335.

Workman, S. W. and McLeod, K. M., 1990. Vegetation of the Savannah River Site: Major Community Types. SRO-NERP-19, Savannah River Ecology Laboratory, Aiken, SC. 